\title{
Nietzsche e a caricatura nazista do super-homem*
}

\author{
Dalcídio Jurandir**
}

\begin{abstract}
Resumo: Resenha crítica publicada no diário carioca Diretrizes, no ano de 1942. O autor resenha o livro Nietzsche, do historiador norte americano Crane Brinton, dando particular atenção ao capítulo VIII: Nietzsche e o Nazismo. A resenha é motivada pela tradução do livro de Brinton para a língua portuguesa, realizada pela Companhia Editora Nacional.
\end{abstract}

Palavras-chave: Nietzsche - Crane Brinton - super-homem nazismo

O escritor americano Crane Brinton escreveu um excelente e oportuno estudo sobre Nietzsche, agora traduzido para a nossa língua, em edição da Com. Editora Nacional. Um livro sem ênfases, preocupado em lançar humanos esclarecimentos sobre as ideias nietzschianas e suas relações com o fascismo, sem as sutilezas e os requintes tão habituais aos delirantes e confusos exegetas do criador de "Assim falou Zaratustra".

Pretende o autor situar a obra do pensador germânico "nas mais gerais correntes de opinião" de nosso tempo, considerando-o simplesmente como político e moralista. Em seu prefácio Crane elucida que, "americano nascido e criado antes da guerra passada, não poderá simpatizar com nazistas, nem, sobretudo, com intelectuais nazistas". Seu livro não é, portanto, um livro neutro, um estudo à margem, coloca-se em posição de combate aberto e desmascarara os arranjos nazistas que tentava fazer do pensamento e das imagens de Nietzsche uma arma e um símbolo da sombria

\footnotetext{
* Resenha publicada no diário carioca Diretrizes, em agosto de 1942, p. 05-21.

*** Dalcídio Jurandir Ramos Pereira (1909-1979). Romancista e jornalista paraense.
}

Cad. Nietzsche, Guarulhos/Porto Seguro, v.36 n.2, p. 143-148, 2015. | 143 
Jurandir, D.

e sanguinária impostura que caiu sobre a Europa. Nunca, na verdade, se pode dizer que Nietzsche é um impostor, sua obra pode nos dar uma falsa interpretação do mundo, uma errada e alucinada crítica dos costumes, a lição de um individualismo anárquico e transcendente, tocado de exaltações proféticas, de estranho dionisismo místico, com o orgulho e a vagabundagem espetacular de Zaratustra. Mas é ainda a arte nietzscheana que nos aproxima desse fabuloso solitário e impede que tumultuosas páginas desapareçam. Hitler, à falta de uma doutrina e de justificações históricas para a sua tática política, recorreu a Nietzsche para pregar e executar o domínio ultrarreacionário e racista sobre os homens. É apenas um nauseabundo e servil instrumento dos magnatas-armamentos e dos policiais da águia prussiana. Nietzsche é um poeta, um não conformista exasperado e doente. Hitler em seu livro medíocre incita-nos a matar judeus, a exaltar a guerra e o saque, a considerar que o problema dominante das nações é o problema da raça. Abrimos o Zaratustra e em meio dos seus poemas a gente nunca deixa de achar belo e inesquecível que o mágico vagabundo exclame: "Eu só poderia acreditar num Deus que soubesse dançar". Zaratustra é muitas vezes um dançarino amável e prega a alegria de viver. Os super-homens de Hitler pregam a alegria de matar, são geralmente mesquinhos, semiloucos, grotescos e sádicos. Falta-lhes aquela preciosa e rara probidade de que falava Zaratustra. $\mathrm{O}$ super-homem em Nietzsche é uma criação poética e em Hitler é uma caricatura de Carlitos.

Crane analisa a influência de Nietzsche na vida intelectual da Europa e diversidade de opiniões e conceitos que se escrevem a respeito do sentido moral e político do filósofo alemão. $\mathrm{O}$ que, porém, melhor caracteriza o livro do escritor americano é a sua análise das contradições feitas pelos nazistas, a fim de transformar Nietzsche em profeta da barbárie hitleriana. Todos os aspectos

144 | Cad. Nietzsche, Guarulhos/Porto Seguro, v.36 n.2, p.143-148, 2015. 
obscuros da obra de Nietzsche são utilizados como excitantes da fúria nazista. Os camisas pardas babam-se ao citar que o "símbolo de todas essas raças aristocráticas é incontestavelmente o animal feroz à magnifica besta loura". Entretanto, os teóricos das Gestapo omitiram o resto do trecho nietzcheano que conclui assim: "não obstante, entre os alemães de hoje e os antigos germânicos, quase não existem semelhanças psicológicas, quanto mais físicas".

Crane diz-nos muito bem que Zaratustra serve à torva embriaguez que empolgou a Alemanha: "Zaratustra não tem programa, não expõe claramente nenhum plano de reforma." "As longas roupagens brancas, as barbas simbólicas, o olhar fosforescente" são recursos mágicos para incutir ao povo que é necessário viver façanhas bárbaras, ouvindo profetas, entre matanças e fogueiras, num cenário de deuses. A irrealidade de Zaratustra, que nos seduz pelo seu caráter essencialmente poético e nunca pelo seu conteúdo político, deforma-se aos olhos dos impostores nazistas como um clima ideal para os seus delírios e para as suas monstruosas aventuras. $\mathrm{O}$ que os hitleristas melhor se utilizam de Nietzsche é a retórica, é o aristocratismos, são as imprecações dos aforismos de um escritor que não se adaptou à sua classe burguesa. Em certo sentido, Nietzsche foi um romântico retardado, um romântico que desejasse uma revolução para reimplantar os melhores tempos da aristocracia medieval, com os símbolos da velha Germânia e os valores perdidos do feudalismo. Dentro de uma como a de Londres e a dos armadores de navios e fabricantes de máquinas da Alemanha, Nietzsche não podia tolerar a sociedade em que se debatia, como um estranho e um evadido, porque ela não correspondia ao seu idealismo aristocrático e nebuloso, que somente se devia sustentar na solidão e na febre da inspiração poética. Nietzsche era um ditador do espírito, um metafísico atolado no Apocalipse, odiando o rebanho humano, 
Jurandir, D.

odiando os capitalistas e jamais compreendendo as vozes que enunciavam uma sociedade nova, cujos valores não seriam os do capital, mas os do trabalho. Como um gênio inumano e despótico, Nietzsche foi o inimigo de sua própria classe e sem querer forneceu pretextos e mitos para que essa classe pudesse adiar a sua queda, com a demagogia e a violência do fascismo. E no próprio Zaratustra vemos, porém, que Nietzsche não poderia ter ficado naquele inconformismo possesso. "Eu sou - diz o vagabundo - de hoje e de antes, mas em mim há qualquer coisa é de amanhã e de depois de amanhã e do futuro". As ideias de Nietzsche não podem culminar na sua própria negação dialética, que é a pseudo ideologia fascista. Sua obra é uma data do espírito, em sua marcha, em suas incertezas e desesperos, em sua luta e sob o peso das terríveis contradições determinadas por uma sociedade que, como disse alguém, não saia da pré-história...

Nietzsche se visse os super-homens de hoje, repetiria o que Zaratustra diz no preâmbulo, a respeito dos macacos que encontra no caminho: "Uma irrisão e uma vergonha"! Hitler e seus comparsas são "aqueles moedeiros falsos, entes retrógrados, disfarçados com palavras solenes, aparatosos, de quem se devia ter muito cuidado".

A ideia de Nietzsche a respeito das multidões era a ideia do rebanho e por isso e por isso queria super-homens. Hitler, "a besta teutônica, ávida de rapinas e vitórias", quer subjugar e calcar na lama as multidões para transformá-las em rebanhos. Por que só assim é possível destacar-se e dar a ilusão de que é o superhomem. Acontece, porém, o contrário e Nietzsche contemplaria, com espanto e náusea, o espetáculo da miséria e do aviltamento fascista. Sua criação não passou, na realidade, de uma besta alucinante, saltando e tropeçando sobre milhões de cadáveres. Um reles histrião desengonçado, tossindo o seu feroz e ridículo palavrório, como na cena de "O grande ditador", e atolado no

146 Cad. Nietzsche, Guarulhos/Porto Seguro, v.36 n.2, p.143-148, 2015. 
sangue de seus pobres e fanáticos soldados.

\begin{abstract}
Critical review published in the journal Diretrizes in 1942. The author reviews the book Nietzsche by the American historian Crane Brinton, with particular emphasis on Chapter VIII: "Nietzsche and Nazism". The review is motivated by Brinton's book translation into Portuguese, conducted by Companhia Editora Nacional
\end{abstract}

Keywords: Nietzsche - Crane Brinton - superman - nazism 
